\title{
Awareness about medico legal aspects and Consumer Protection Act (CPA) among dental fraternity
}

\author{
Priyanka Goel $^{1}$, Pragya Sharma ${ }^{2}$, Preeti Sharma ${ }^{3, *}$, Shubhra Vaish $^{4}$ \\ ${ }^{1,2}$ BDS Student, ${ }^{3}$ Post Graduate Student, ${ }^{4}$ Professor, ${ }^{3,4}$ Dept. of Periodontology and Oral Implantology, I.T.S. Centre for Dental \\ Studies and Research, Muradnagar, Ghaziabad, Uttar Pradesh, India
}

*Corresponding Author:

Email: drpreeti010@gmail.com

\begin{abstract}
Introduction: A dentist is a healthcare professional providing care for the patient, as a physician. There has been increase in the number of patients challenging the dentist's authority over treatment planning and consent issues in the past few years. Thus, while providing the oral healthcare services a dentist has to follow certain set of standards in almost all the activities related to the management of patient. Failure to exercise such practice could invite litigation in the name of malpractice.

Therefore, this study was performed to assess the level of knowledge and understanding relevant to CPA and Medico legal aspects that can affect Dentists.

Materials and Methods: A self-structured validated questionnaire comprising of 15 questions related to medicolegal aspect and CPA was designed. A total of 150 dental professionals were surveyed. ; 50 were undergraduates, 50 were postgraduates and 50 were dental faculty. Chi-square test was used to compare the awareness of medico-legal issues among dentists.

Result: The CPA awareness scores were significantly higher among faculty when compared with those of undergraduates and postgraduates. About $44.0 \%$ of BDS students, $84.0 \%$ of MDS students and $94.0 \%$ of the dental faculty are aware about CPA. Nearly $20.0 \%$ of the BDS students, $42.0 \%$ of the MDS students and $52.0 \%$ of the dental faculty know the legal procedures to tackle COPRA/CPA.

Conclusion: Considering the present situation, a better understanding of CPA is essential for dentists in India to be on the safer side and an educational program would be useful to increase the understanding and confidence of dentists in any medical legal jurisprudence to avoid any lawsuit.
\end{abstract}

Keywords: Bachelor of Dental Surgery (BDS), Consumer Protection Act (CPA), Dental Council of India (DCI), Master of Dental Surgery (MDS), postgraduate (PG) students.

\section{Introduction}

The practice of medicine is one of the noblest professions in the world. However, the changing doctor-patient relationship and commercialization of modem medical practice has affected this profession. ${ }^{1} \mathrm{~A}$ dentist is a healthcare professional who providescare for the patient, as a physician does. There has been rise in the number of patients who challenge the dentist's authority over management of disease and consent issues in the past few years. Now a days, a significant number of dentists are being summoned to court by patients. Therefore, it is essential that dentists should have an adequate knowledge of the law for the implications on their profession. ${ }^{2}$ Thus, while providing the oral healthcare services a dentist must be aware about some set of standards in maintaining records of almost all the activities related to the management of patient. Failure to exercise such practice could invite litigation in the name of malpractice. The factors that should be considered with utmost care while managing a patient are consent, a detailed case history recording, well-understood drug prescription policy and knowledge of emergency situation handling. ${ }^{3}$

In India, the Consumer protection act [CPA] was enacted in 1986, to protect the interest of consumers. It was only on the 13th November 1995, which the medical/dental profession was brought within the ambit of CPA by the supreme court of India. ${ }^{4}$ Therefore, this study was performed to evaluate the level of knowledge and understanding related to Consumer Protection Act and Medico legal aspects among dental professionals. ${ }^{4}$

\section{Materials and Methods}

This is a cross-sectional study in which a survey was conducted using a self-constructed written questionnaire among the dentists in ITS dental college from October 2018 to November 2018. A selfstructured questionnaire was comprised of 15 questions written in English. (Fig 1.) Questions were based on informed consent, consumer protection act (CPA) and medico legal aspects. A total of 150 dental professionals were surveyed; 50 were undergraduates, 50 were postgraduates and 50 were dental faculty. The participants were informed about the nature of the study and were asked to respond to the set of 15 questions. The participants had been given full explanation on how to fill questionnaire, and to answer all the questions was mandatory. Prior to the data collection, the questions were pretested among a group of 15 professionals in order to ensure the level of validity and degree of repeatability. All the participants belonging to dental specialty and having interest in participating were included in the study. 


\section{Statistical analysis}

The Statistical Analysis Software (SPSS version 16) was used for data processing and analysis. The chi-

\section{Designation (UG/PG/Faculty): \\ Gender:}

What you do?: Student/Private Practitioner/Private practitioner + Faculty

Experience in dental field ( in years):

1. Do you take informed consent from the patient before starting any treatment?
(a) Yes, written consent
B) Yes, oral consent
(b) $\mathrm{No}$
2. Do you give detailed explanation of the procedure and explain the complications associated with the treatment or anaesthesia?
(a) Yes
(b) No
3. For a patient under 15 years of age, consent for examination is taken from?
(a) Patient
(b) Parent/Guardian
(c) No consent is required

4. Do you provide the copy of the consent form to the patient?

(a) Always

(b) Ask for the reason

(c) Refuse

5. Do you collect the past history of any medical condition/drug allergy and reactions of your patients before starting the treatment?

(a) Yes

6. Is the written consent obtained in the local language?

(a) Yes

(b) No

7. Do you give the success and failure rates of any dental treatment before starting?
(a) Yes
(b) No

\section{Fig. 1 Questionaire of this study}

\section{Results}

A sample of 150 respondents was selected from each of BDS, MDS and Dental Faculty groups. 50 BDS students, 50 MDS students and 50 dental faculty comprised the group of 150 respondents.

\section{Awareness and Knowledge regarding informed consent and history taking}

Table 1 shows that nearly $58.0 \%$ of the BDS students, $100.0 \%$ of the MDS students and $100.0 \%$ of the Dental faculty give detailed explanation of the procedure and explain the complications associated with the treatment or anesthesia. About $84.0 \%$ of the BDS students, $88.0 \%$ of MDS students and $100.0 \%$ of the dental faculty square test was used to evaluate the result statistically. $\mathrm{P}<0.05$ was considered as statistically significant.

8. Is a hospital legally bound to maintain records?

(a) Yes

(b) No

9. Are you aware about CPA?

(a) Yes

(b) No

10. Do you know the legal procedures to tackle COPRA/CPA?

(a) Yes

(b) No

11. What according to you is a punishable offence?

(a) Death on Dental chair

(b) Extracting a wrong tooth/RCT of wrong tooth

(c) None of the above

(d) both (a) and (b)

12. According to you who is a not liable(for any punishment) dentist?

(a) Dentists with independent practice rendering only free services.

(b) Doctors/hospitals paid by an insurance firm for treatment of a client or an employer for the treatment of an employee

(c) Dentists in hospitals which do not charge their patients

(d) All of the above

13. In case you diagnose the patient with AIDS, can you refuse the patient for treatment?

(a) Yes

(b) No

14. Can a patient sue a doctor for rejecting an emergency case/medically compromised case?

(a) Yes

(b) No

15. Do you think that the present education scenario is sufficient to know about medico-legal responsibilities?
(a) Yes
(b) No

collect the past history of any medical condition/drug allergy and reactions of your patients before starting the treatment. $64.0 \%$ of the BDS students, $87.8 \%$ of the MDS students and $91.8 \%$ dental faculty obtain in the local language. Almost $60.0 \%$ of the BDS students, $60.0 \%$ of the MDS students and $96.0 \%$ of the dental faculty give the success and failure rates of any dental treatment before starting. 
Table 1: Knowledge and awareness regarding informed consent and history taking

\begin{tabular}{|c|c|c|c|c|c|c|}
\hline \multirow{2}{*}{ Questions } & \multicolumn{2}{|c|}{$\begin{array}{c}\mathrm{UG} \\
\mathrm{n}=50\end{array}$} & \multicolumn{2}{|c|}{$\begin{array}{c}\mathrm{PG} \\
\mathrm{n}=50\end{array}$} & \multicolumn{2}{|c|}{$\begin{array}{l}\text { FACULTY } \\
\mathrm{n}=50\end{array}$} \\
\hline & $\begin{array}{l}\text { YES } \\
\mathrm{n}(\%)\end{array}$ & $\begin{array}{l}\text { NO } \\
\mathrm{n}(\%)\end{array}$ & $\begin{array}{l}\text { YES } \\
\text { n(\%) }\end{array}$ & $\begin{array}{l}\text { NO } \\
\text { n(\%) }\end{array}$ & $\begin{array}{l}\text { YES } \\
\text { n(\%) }\end{array}$ & $\begin{array}{l}\text { NO } \\
\text { n(\%) }\end{array}$ \\
\hline $\begin{array}{l}\text { Do you give detailed explanation of } \\
\text { the procedure and explain the } \\
\text { complications associated with the } \\
\text { treatment or anesthesia? }\end{array}$ & $\begin{array}{l}29 \\
58.0 \%\end{array}$ & $\begin{array}{c}21 \\
42.0 \%\end{array}$ & $\begin{array}{c}50 \\
100.0 \\
\frac{0}{0}\end{array}$ & 0 & $\begin{array}{c}50 \\
100.0 \%\end{array}$ & $\begin{array}{c}0 \\
0 \%\end{array}$ \\
\hline $\begin{array}{l}\text { Do you collect the past history of any } \\
\text { medical condition/drug allergy and } \\
\text { reactions of your patients before } \\
\text { starting the treatment? }\end{array}$ & $\begin{array}{c}42 \\
84.0 \%\end{array}$ & $16.0 \%$ & $\begin{array}{c}44 \\
88.0 \%\end{array}$ & $12.0 \%$ & $\begin{array}{c}50 \\
100.0 \%\end{array}$ & $0.0 \%$ \\
\hline $\begin{array}{l}\text { Is the written consent obtained in the } \\
\text { local language? }\end{array}$ & $\begin{array}{l}32 \\
64.0 \%\end{array}$ & $\begin{array}{l}18 \\
36.0 \%\end{array}$ & $\begin{array}{c}43 \\
87.8 \%\end{array}$ & $12.2 \%$ & $\begin{array}{c}45 \\
91.8 \%\end{array}$ & $\begin{array}{c}4 \\
8.2 \%\end{array}$ \\
\hline $\begin{array}{l}\text { Do you give the success and failure } \\
\text { rates of any dental treatment before } \\
\text { starting? }\end{array}$ & $\begin{array}{l}30 \\
60.0 \%\end{array}$ & $\begin{array}{c}20 \\
40.0 \%\end{array}$ & $\begin{array}{l}33 \\
66.0 \%\end{array}$ & $\begin{array}{c}17 \\
34.0 \%\end{array}$ & $\begin{array}{c}48 \\
96.0 \%\end{array}$ & $\begin{array}{l}2 \\
4.0 \%\end{array}$ \\
\hline
\end{tabular}

\section{Awareness regarding Consumer Protection Act (CPA)}

Table 2 shows that nearly $88.0 \%$ of BDS students, $98.0 \%$ of MDS students and $100.0 \%$ of the dental faculty know that a hospital is legally bound to maintain records. About $44.0 \%$ of BDS students, $84.0 \%$ of MDS students and $94.0 \%$ of the dental faculty were aware about CPA. $20.0 \%$ of the BDS students, $42.0 \%$ of the MDS students and $52.0 \%$ of the dental faculty know the legal procedures to tackle COPRA/CPA. In case of a patient suffering from AIDS, about $32.0 \%$ of
BDS students, $10.0 \%$ of MDS students and $0.0 \%$ of the dental faculty said that they can refuse the patient to treat. Almost $68.0 \%$ of BDS students, $46.0 \%$ of MDS students and $56.0 \%$ of the dental faculty said that a patient can sue a doctor for rejecting an emergency case/medically compromised case. $26.0 \%$ of BDS students, $24.0 \%$ of MDS students and $32.0 \%$ of dental faculty answered that the present education scenario is sufficient to know about the medico legal responsibilities.

\section{Table 2: Awareness regarding Consumer Protection Act (CPA)}

\begin{tabular}{|c|c|c|c|c|c|c|}
\hline \multirow[b]{2}{*}{ Questions } & \multicolumn{2}{|c|}{$\begin{array}{c}\mathbf{U G} \\
\mathbf{n}=\mathbf{5 0}\end{array}$} & \multicolumn{2}{|c|}{$\begin{array}{c}\text { PG } \\
\mathbf{n}=\mathbf{5 0}\end{array}$} & \multicolumn{2}{|c|}{$\begin{array}{c}\text { FACULTY } \\
\mathbf{n}=\mathbf{5 0}\end{array}$} \\
\hline & $\begin{array}{l}\text { YES } \\
\mathrm{n}(\%)\end{array}$ & $\begin{array}{l}\mathrm{NO} \\
\mathrm{n}(\%)\end{array}$ & $\begin{array}{l}\text { YES } \\
\mathrm{n}(\%)\end{array}$ & $\begin{array}{l}\mathrm{NO} \\
\mathrm{n}(\%)\end{array}$ & $\begin{array}{l}\text { YES } \\
\mathrm{n}(\%)\end{array}$ & $\begin{array}{l}\mathrm{NO} \\
\mathrm{n}(\%)\end{array}$ \\
\hline $\begin{array}{l}\text { Is a hospital legally bound to } \\
\text { maintain records? }\end{array}$ & $\begin{array}{c}44 \\
88.0 \%\end{array}$ & $\begin{array}{c}6 \\
12.0 \%\end{array}$ & $\begin{array}{c}49 \\
98.0 \%\end{array}$ & $\begin{array}{c}1 \\
2.0 \%\end{array}$ & $\begin{array}{l}50 \\
100.0 \%\end{array}$ & $\begin{array}{c}0 \\
0.0 \%\end{array}$ \\
\hline Are you aware about CPA? & $\begin{array}{c}22 \\
44.0 \%\end{array}$ & $\begin{array}{l}28 \\
56.0 \%\end{array}$ & $\begin{array}{c}43 \\
84.0 \%\end{array}$ & $16.0 \%$ & $\begin{array}{c}47 \\
94.0 \%\end{array}$ & $\begin{array}{l}3 \\
6.0 \%\end{array}$ \\
\hline $\begin{array}{l}\text { Do you know the legal procedures } \\
\text { to tackle COPRA/CPA? }\end{array}$ & $\begin{array}{c}10 \\
20.0 \%\end{array}$ & $\begin{array}{c}40 \\
80.0 \%\end{array}$ & $\begin{array}{c}21 \\
42.0 \%\end{array}$ & $\begin{array}{c}29 \\
58.0 \%\end{array}$ & $\begin{array}{c}26 \\
52.0 \%\end{array}$ & $\begin{array}{c}24 \\
48.0 \%\end{array}$ \\
\hline $\begin{array}{l}\text { In case you diagnose the patient } \\
\text { with AIDS, can you refuse the } \\
\text { patient for treatment? }\end{array}$ & $\begin{array}{c}16 \\
32.0 \%\end{array}$ & $\begin{array}{c}34 \\
68.0 \%\end{array}$ & $10.0 \%$ & $\begin{array}{c}45 \\
90.0 \%\end{array}$ & $\begin{array}{c}0 \\
0.0 \%\end{array}$ & $\begin{array}{c}50 \\
100.0 \%\end{array}$ \\
\hline $\begin{array}{l}\text { Can a patient sue a doctor for } \\
\text { rejecting an emergency } \\
\text { case/medically compromised case? }\end{array}$ & $\begin{array}{c}34 \\
68.0 \%\end{array}$ & $\begin{array}{c}16 \\
32.0 \%\end{array}$ & $\begin{array}{c}27 \\
54.0 \%\end{array}$ & $\begin{array}{c}23 \\
46.0 \%\end{array}$ & $\begin{array}{c}22 \\
44.0 \%\end{array}$ & $\begin{array}{c}28 \\
56.0 \%\end{array}$ \\
\hline $\begin{array}{l}\text { Do you think that the present } \\
\text { education scenario is sufficient to } \\
\text { know about the medicolegal } \\
\text { responsibilities? }\end{array}$ & $\begin{array}{c}13 \\
26.0 \%\end{array}$ & $\begin{array}{c}37 \\
74.0 \%\end{array}$ & $\begin{array}{c}12 \\
24.0 \%\end{array}$ & $\begin{array}{c}38 \\
76.0 \%\end{array}$ & $\begin{array}{c}16 \\
32.0 \%\end{array}$ & $\begin{array}{c}34 \\
68.0 \%\end{array}$ \\
\hline
\end{tabular}




\section{Discussion}

This study was an effort to investigate the awareness of medico-legal issues among Dental college health professionals in ITS Dental College, Muradnagar. The result of this study provides a valuable insight into awareness of medico-legal issues and need to improve their knowledge, attitude and practices regarding medico-legal issues.

The guidelines on informed consent have been issued by The Supreme Court of India. According to that, before starting any treatment, a doctor must ask for and secure the consent of the patient. ${ }^{4}$ The consent obtained should comprise the nature and method of the treatment and it's rationale, benefits and outcome, any alternative treatment if available, knowledge of the considerable risks, and the unfavorable consequences of denying treatment. For legal suits, preservation of judicial records is necessary for a minimum of 2 years in consumer cases (The CPA, 1986) and 3 years in civil cases with no time limit in criminal cases. ${ }^{4} \mathrm{~K}$. Singh et al in Udaipur, ${ }^{5}$ Rajasthan, India found in his study that medical professionals are more aware about CPA as compared to dental professionals. In our study, we could see significant difference between the UGs, PGs and faculty regarding the awareness of CPA.

In the present study, most of the participants knew about the medical code of ethics. They think that knowledge of ethics is extremely important. Most of the subjects were aware about the knowledge of record keeping of the patients and results were higher than the study done in 2009 by Makhani C.S $S^{6}$ in Indore .All patient related information like medical history, chart notes, radiographs, and photographs must be meticulous, and it is necessary for the documents to beduly signed and dated. Under Article $51 \mathrm{~A}(\mathrm{~h})$ of the Constitution of India, there is a moral obligation on the doctor, and a legal duty, to maintain and preserve medical, medico-legal, and legal documents in the best interests of social and professional justice ${ }^{7}$.Our study revealed that knowledge regarding the aims and objectives of CPA and it application in regard to our field of practice is limited, similar to studies conducted by Jasuma et al. ${ }^{8}$ In our study each dentist have knowledge of informed consent and this is in favour of the study carried by Heywood R. in 2007. ${ }^{9}$ Consent requires so that patient can fully understand the information given, but if the patient is debilitated due to a serious illness/mental condition, decisions should be made by a suitable surrogate. ${ }^{10}$

The result of our study showed that senior doctors have better level of knowledge than juniors. Similar results were found by Sing $\mathrm{K}$ et al among health care professionals in Udaipur ${ }^{5}$ and Jasuma et al in Vadodra. ${ }^{8}$ As health professionals have limited knowledge, so there is an increased risk of malpractice, especiallyin condition of complex clinical cases. In addition, the knowledge of patient population has been expanded and they are now more aware of their rights, consequently taking action by contacting the consumer forum to lodge their complaints. ${ }^{11}$ In our study approximately $80 \%$ of the dental professionals take consent from the patients prior to the start of any procedure which is less as compared to the findings in a study by Sumanth Prasad et al. ${ }^{12}$

In our study, sampling was conducted in one institute only.Although the participants taken in our study were from different backgrounds; still it cannot predict the overall situation in whole country. Also, the sample size of the study was less as compared to the studies previously done by Radhika et $\mathrm{al}^{2}$ in Chennai and S Senthikumar et $\mathrm{al}^{1}$ in Tamilnadu.

It was found that the senior dentistsin our study were significantly more aware compared to the junior dentists. This might be due to the reason that with increase in knowledge and exposure, awareness also increases. The number of patients who are more educated and well aware of their rights, are increasing day by day, that's why the approach to the consumer forum to register grievances and complaints has been increased significantly. Therefore, there is a need to spread awareness about the legal issues and ways to tackle them.

\section{Conclusion}

The study participants, in our study, have knowledge about informed consent and medical legal aspects but when it came to real objectives of consumer protection act and methods of filing cases their knowledge was just above average. So, dental health professionals need to update their understanding on consumer protection act and its amendments.As far as present situation is considered, a better understanding of CPA is necessaryfor dentists in India to be on the safer side and an educational program would be useful to increase the understanding and confidence of dentists in any medical legal jurisprudence to avoid any problem.Therefore, an urgent need is recommended to update the understanding of medico legal issues for medical health professionals to be on safer side legally.

\section{Conflict of Interest: None}

\section{References}

1. Shanthikumar S, Reddy VC, Ingle NA. Awareness of medico-legal issues among medical and dental college health professionals. J Ind Asso Pub Health Dentistry 2013;11(3):44-50

2. Radhika T, Nadeem J, Arthi R, Nithya S. Awareness about Medico Legal Aspects and Consumer Protection Act among Dentists. J Forensic Odontostomatol 2017;35(1):1-8.

3. Vashist A, Parhar S, Gambhir RS, Sohi RK, Talwar PP. Legal modalities in dental patient management and professional misconduct. SRM J Res Dent Sci 2014;5:916

4. Supreme court of India. Indian Medical Association vs V.P. Shantha. Judgement Information system 1995;6 SCC- 651. 
5. Singh G, Gambhir RS, Singh S, Talwar PS, Munjal V. Knowledge and awareness of the Consumer Protection Act among dental professionals in India: A systematic review . Indian J Dent 2014;5:146-51

6. Makhani CS, Petkar MR, Chavan KD, Rao TV. Indian J Forensic Med Pathol 2011;4(4):151-5.

7. Astekar M, Saawarn S, Ramesh G, Saawarn N. Maintaining dental records: Are we ready for forensic needs? J Forensic Dent Sci 2011; 3: 52-7.

8. Rai JJ, Acharya RV, Dave D. Knowledge and Awareness among interns and residents about medical law and negligence in a medical college in Vadodara - A Questionnaire Study. J Dent Med Sci 2013;3(4):32-8.

9. Heywood R., Macaskill A, Williams K, Medical students' perceptions of informed consent: legal reflections on clinical education. $J$ Professional Negligence 2007;23(3):151-64.

10. Yousuf R M, Fauzi A R M, How S H, Rasool A G, Rehana K Awareness, knowledge and attitude towards informed consent among doctors in two different cultures in Asia: a cross-sectional comparative study in Malaysia and Kashmir, India. Singapore Med J 2007;48(6):559-65.

11. Al-Ammar W, Guile EE. A one year survey of dental malpractice claims in Riyadh. Saudi Dent $J$ 2000;12(2):95-9.

12. Prasad S, Menon I, Dhingra C, Anand R. Awareness of consumer protection act among dental health professionals in dental schools of Ghaziabad, India. OHDM 2013;12:262-68.

How to cite the article: Goel P, Sharma P, Preeti, Vaish S. Awareness about medico legal aspects and Consumer Protection Act (CPA) among dental fraternity. J Dent Specialities 2018;6(2):131-135. 